\title{
Selective stimulation of catecholamine release from bovine adrenal chromaffin cells by an ionotropic purinergic receptor sensitive to 2-methylthio ATP
} Ângelo R Tomé ${ }^{1,2}$, Enrique Castro ${ }^{3}$, Rosa M Santos ${ }^{1,2}$ and Luís M Rosário*1,2

Address: ${ }^{1}$ Center for Neurosciences and Cell Biology, University of Coimbra, Coimbra, Portugal, ${ }^{2}$ Department of Biochemistry, Faculty of Sciences and Technology, University of Coimbra, P.O. Box 3126, 3001-401 Coimbra, Portugal and ${ }^{3}$ Department of Biochemistry, Molecular Biology and Physiology, Faculty of Medicine and Health Sciences, University of Las Palmas de Gran Canaria, Las Palmas, Spain

Email: Ângelo R Tomé - atome@ci.uc.pt; Enrique Castro - ecastro@dbbf.ulpgc.es; Rosa M Santos - rmsantos@ci.uc.pt; Luís M Rosário* - lrosario@ci.uc.pt

* Corresponding author

Published: 20 June 2007

BMC Neuroscience 2007, 8:4| doi:|0.||186/|47|-2202-8-4|
Received: 13 February 2007

Accepted: 20 June 2007

This article is available from: http://www.biomedcentral.com/I47I-2202/8/4I

(C) 2007 Tomé et al; licensee BioMed Central Ltd.

This is an Open Access article distributed under the terms of the Creative Commons Attribution License (http://creativecommons.org/licenses/by/2.0), which permits unrestricted use, distribution, and reproduction in any medium, provided the original work is properly cited.

\begin{abstract}
Background: 2-Methylthioadenosine 5'-triphosphate (2-MeSATP), formerly regarded as a specific P2Y (metabotropic) purinergic receptor agonist, stimulates $\mathrm{Ca}^{2+}$ influx and evokes catecholamine release from adrenal chromaffin cells. These cells express P2Y and P2X (ionotropic) purinoceptors, with the latter providing an important $\mathrm{Ca}^{2+}$ influx pathway. Using single cell calcium imaging techniques, we have determined whether 2-MeSATP might be a specific P2X receptor agonist in bovine chromaffin cells and assessed the relative role of $\mathrm{P} 2 \mathrm{X}$ and $\mathrm{P} 2 \mathrm{Y}$ receptors on catecholamine secretion from these cells.

Results: ATP raised the $\left[\mathrm{Ca}^{2+}\right]_{i}$ in $\sim 50 \%$ of the cells. Removing extracellular $\mathrm{Ca}^{2+}$ suppressed the $\left[\mathrm{Ca}^{2+}\right]_{i}$-raising ability of 2-MeSATP, observed in $\sim 40 \%$ of the ATP-sensitive cells. This indicates that 2-MeSATP behaves as a specific ionotropic purinoceptor agonist in bovine chromaffin cells. The $2-$ MeSATP-induced $\left[\mathrm{Ca}^{2+}\right]_{i}$-rises were suppressed by PPADS. UTP raised the $\left[\mathrm{Ca}^{2+}\right]_{i}$ in $\sim 40 \%$ of the ATP-sensitive cells, indicating that these expressed $\mathrm{Ca}^{2+}$-mobilizing $\mathrm{P} 2 \mathrm{Y}$ receptors. UTP-sensitive receptors may not be the only P2Y receptors present, as suggested by the observation that $\sim 20 \%$ of the ATP-sensitive pool did not respond to either 2-MeSATP or UTP. The average sizes of the ATP- and 2-MeSATP-evoked $\left[\mathrm{Ca}^{2+}\right]_{i}$ responses were identical in UTP-insensitive cells. 2-MeSATP stimulated $\mathrm{Ca}^{2+}$ influx and evoked catecholamine release, whereas UTP elicited $\mathrm{Ca}^{2+}$ release from intracellular stores but did not evoke secretion. 2-MeSATP-induced secretion was strongly inhibited by $\mathrm{Cd}^{2+}$ and suppressed by extracellular $\mathrm{Ca}^{2+}$ or $\mathrm{Na}^{+}$removal. TTX inhibited 2-MeSATPevoked secretion by $\sim 20 \%$.
\end{abstract}

Conclusion: 2-MeSATP is a specific P2X purinoceptor agonist and a potent secretagogue in bovine chromaffin cells. Activation of 2-MeSATP-sensitive receptors stimulates $\mathrm{Ca}^{2+}$ influx mainly via voltage-sensitive $\mathrm{Ca}^{2+}$ channels. For the most part, these are activated by the depolarization brought about by $\mathrm{Na}^{+}$influx across $\mathrm{P} 2 \mathrm{X}$ receptor pores. 


\section{Background}

Extracellular ATP plays an important role in catecholamine release from adrenal chromaffin cells, either facilitating cholinergic stimulation via ionotropic (P2X) purinoceptors or inhibiting evoked release through a delayed action on metabotropic (P2Y) purinoceptors (see [1] and references therein). The latter may provide the basis for an auto-inhibitory feedback loop involving both autocrine and paracrine interactions. There are at least seven P2X receptor subunits encoded by distinct genes, which may form homo- or heterotrimeric ionotropic purinoceptors; functional P2X receptors are $\mathrm{Ca}^{2+}$-permeable and provide an important $\mathrm{Ca}^{2+}$ influx pathway, both in neurons and other cell types (for review see $[2,3]$ ).

The presence of P2X receptor subtypes in chromaffin cells is species-dependent [4] (see [3] for a review). Thus, rat chromaffin cells have either been reported to lack P2X receptors [4] or to show a variable expression of P2X receptor subtypes $\left(\mathrm{P} 2 \mathrm{X}_{1}, \mathrm{P} 2 \mathrm{X}_{2}, \mathrm{P} 2 \mathrm{X}_{5}\right.$ and $\left.\mathrm{P} 2 \mathrm{X}_{7}\right)[5,6]$; there is also some evidence that these cells express $\mathrm{P} 2 \mathrm{X}_{4}$ receptors in aged animals [7]. Guinea-pig chromaffin cells seem to express $\mathrm{P} 2 \mathrm{X}_{6}$ receptors [8], although functional studies point strongly to the presence of $\mathrm{P}_{2} \mathrm{X}_{2}$-like receptors [4]. There are no studies reporting the expression of specific $\mathrm{P} 2 \mathrm{X}$ receptor subtypes in bovine chromaffin cells. However, the presence of P2X receptors in these cells has been suggested by functional studies involving mostly cytosolic free $\mathrm{Ca}^{2+}$ measurements [9-11]. ATP-evoked inward currents have been detected in a limited fraction of the cells [12]. The prevailing P2Y receptor subtype in bovine chromaffin cells seems to be an UTP-sensitive, $\mathrm{G}_{\mathrm{i} /}$ o-coupled P2Y receptor $[1,10,13]$.

ATP and other purinergic agonists evoke catecholamine release from either whole glands or isolated chromaffin cells $[9,10,14]$. This action is strictly $\mathrm{Ca}^{2+}$-dependent, suggesting that it might be mediated by either $\mathrm{Ca}^{2+}$ influx through the receptor-associated pores, opening of voltagesensitive $\mathrm{Ca}^{2+}$ channels or both. Studying P2X receptormediated modulation of chromaffin cell function has been made difficult by the lack of specific agonists and antagonists of P2X receptor subtypes. 2-MeSATP, for example, has been classically regarded as a P2Y receptor agonist; more recently, however, several P2Y receptor subtypes have been found to be insensitive to the ATP derivative [2,3]. Moreover, 2-MeSATP is now known to activate P2X receptor subtypes [15]. There is evidence that 2MeSATP behaves as a P2X agonist in guinea-pig chromaffin cells, as assessed by its ability to evoke inward currents $[4,16]$. Previous studies provided conflicting evidence regarding the action of 2-MeSATP on cytosolic free $\mathrm{Ca}^{2+}$ concentration $\left(\left[\mathrm{Ca}^{2+}\right]_{\mathrm{i}}\right)$ in bovine chromaffin cells, with one study reporting sizeable responses [11] and another feeble and sporadic responses [9]. Whether 2-MeSATP might discriminate between $\mathrm{P} 2 \mathrm{X}$ and $\mathrm{P} 2 \mathrm{Y}$ receptors in chromaffin cells remains unknown.

In this work, we aimed at establishing 2-MeSATP as a specific P2X receptor agonist in bovine chromaffin cells by single-cell calcium imaging. We then investigated the effects of 2-MeSATP and UTP on catecholamine release, aiming at clarifying the relative role of $\mathrm{P} 2 \mathrm{X}$ and $\mathrm{Ca}^{2+}$ mobilizing P2Y receptors.

\section{Results \\ $\left[\mathrm{Ca}^{2+}\right]_{i}$ rises evoked by purinoceptor agonists}

$\left[\mathrm{Ca}^{2+}\right]_{\mathrm{i}}$ changes evoked by ATP receptor agonists were monitored by digital fluorescence imaging of the $\mathrm{F}_{340} / \mathrm{F}_{380}$ fura-2 fluorescence ratio $(\Delta \mathrm{R})$. Only cells that displayed sizeable $\left[\mathrm{Ca}^{2+}\right]_{\mathrm{i}}$ responses to $10 \mu \mathrm{M}$ 1,1-dimethyl-4-phenylpiperazinium iodide (DMPP), an established agonist of acetylcholine nicotinic receptors in chromaffin cells, were considered for the study. To this end, cells were perifused at the tail of the experiments with $10 \mu \mathrm{M}$ DMPP for brief periods of time. Our first basic protocol was to stimulate chromaffin cells with ATP, UTP and 2-MeSATP in order to investigate whether UTP-sensitive cells might also be sensitive to 2-MeSATP. Cells were typically subjected to $\sim 60 \mathrm{~s}$ pulses of solutions containing each purinoceptor agonist and washed extensively for at least $10 \mathrm{~min}$ to minimize receptor desensitization at the time of the next challenge.

Typical pseudocolor fura-2 fluorescence images are depicted in Fig. 1(A-D). Representative time courses of $\left[\mathrm{Ca}^{2+}\right]_{i}$ changes for selected chromaffin cells are depicted in E. Resting $\left[\mathrm{Ca}^{2+}\right]_{\mathrm{i}}$ was low prior to stimulation (A, blue). Challenging cells with $100 \mu \mathrm{M}$ ATP elicited sizeable, albeit variable peak $\left[\mathrm{Ca}^{2+}\right]_{i}$ responses from a large pool of chromaffin cells (B and $\mathrm{E}$; green, yellow or red). It is noteworthy that some cells did not respond to ATP (e.g. cell 4). Several cells (e.g. cell 1) exhibited pronounced $\left[\mathrm{Ca}^{2+}\right]_{i}$ rises in response to ATP but not $100 \mu \mathrm{M}$ UTP. Exposure to $100 \mu \mathrm{M}$ 2-MeSATP invariably increased the $\left[\mathrm{Ca}^{2+}\right]_{\mathrm{i}}$ in these cells. In contrast, several cells (e.g. cell 2) responded to both ATP and UTP. For the most part these cells did not respond at all to 2-MeSATP. A fraction of the ATP-sensitive cells responded both to UTP and 2-MeSATP (e.g. cell 3).

The statistical assessment of the $\left[\mathrm{Ca}^{2+}\right]_{\mathrm{i}}$ responses of chromaffin cells to UTP and 2-MeSATP is presented in Fig. 1F in the form of a 3D histogram. The column at the origin of the histogram (blue) depicts cells that did not respond both to UTP and 2-MeSATP (137 in 234 cells, i.e. 59\%); ATP evoked $\left[\mathrm{Ca}^{2+}\right]_{\mathrm{i}}$ rises in 27 of these cells. Cells displaying a variable response to 2-MeSATP and no UTP response (orange) accounted for approximately $30 \%$ of the ATPsensitive pool; the mean size of the 2-MeSATP-evoked $\left[\mathrm{Ca}^{2+}\right]_{\mathrm{i}}$ responses was not significantly different from the 

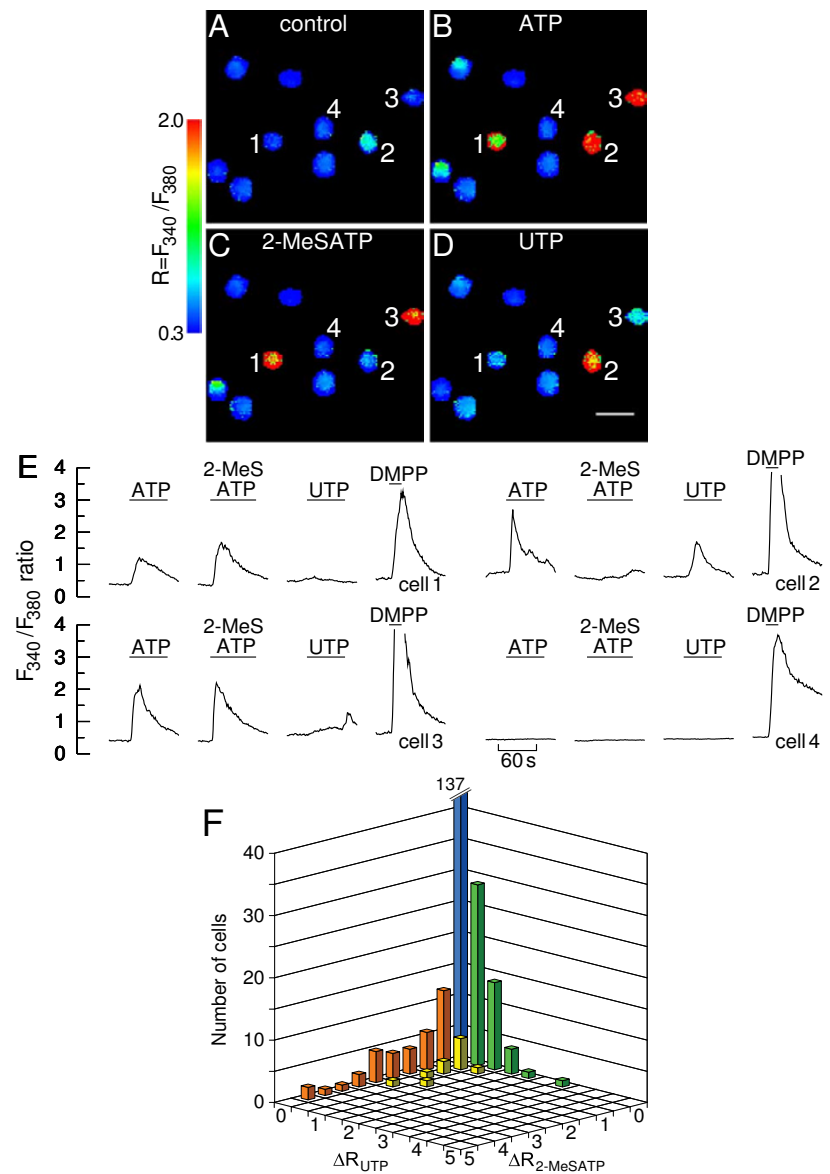

\section{Figure I}

Calcium responses to ATP, UTP and 2-MeSATP. A-D. Calcium images showing a group of chromaffin cells before $(A$, "control") and during stimulation with $100 \mu \mathrm{M}$ ATP (B), 100 $\mu M$ 2-MeSATP (C) and $100 \mu M$ UTP (D). At the end of each experiment cells were stimulated with $10 \mu$ M DMPP. Cells were allowed to rest for $\sim 10$ min between consecutive stimulations. The fura-2 fluorescence ratio $F_{340} / F_{380}$ was determined for each cell in a field on a pixel-by-pixel basis. Images were coded in pseudocolor to show differences in the $F_{340} / F_{380}$ ratio. The images corresponding to agonist stimulation (B-D) were captured at the response peaks. Calibration bar: $50 \mu \mathrm{m}$; E. Time courses of changes in $F_{340} / F_{380}$ fluorescence ratio for a 2-MeSATP-sensitive/UTP-insensitive cell (cell I), an UTP-sensitive/2-MeSATP-insensitive cell (cell 2), a cell displaying a mixed response (cell 3 ) and an ATP-insensitive cell (cell 4). The lines denote superfusions with DMPP or purinergic agonists. Some of the peak responses to DMPP were truncated for scaling reasons; F. Frequency distribution histogram of calcium responses. Changes in $\Delta R=F_{340} / F_{380}$ were determined from the experiment depicted in A-D and 2 similar experiments ( $\mathrm{n}$ $=234$ cells). The column at the origin represents cells that did not respond to either UTP or 2-MeSATP $(\Delta \mathrm{R}<0.5, \mathrm{n}=137$ cells). This column was truncated for scaling reasons. Columns in orange: cells responding to 2-MeSATP only; columns in green: cells responding to UTP only; columns in yellow: cells exhibiting mixed responses.
ATP responses in these cells $(1.53 \pm 1.22$ vs. $1.55 \pm 1.18$, respectively; $\mathrm{n}=37$ cells, $\mathrm{p}=0.8)$. UTP-sensitive cells (green) were for the most part (approximately $40 \%$ of the ATP-sensitive pool) insensitive to 2-MeSATP, although a minority (ca. 8\%, yellow) displayed a mixed sensitivity. The mean sizes of the UTP and ATP responses in UTP-sensitive/2-MeSATP-insensitive cells were $0.71 \pm 0.61$ and $0.92 \pm 0.73$, respectively $(\mathrm{n}=49$ cells; statistically different, $\mathrm{p}<0.0001)$.

None of the cells responding to 2-MeSATP in presence of $\mathrm{Ca}^{2+}$ responded in the virtual absence of extracellular $\mathrm{Ca}^{2+}$ (Fig. 2A,B,E), suggesting that the ATP derivative is a specific $\mathrm{P} 2 \mathrm{X}$ receptor agonist in bovine chromaffin cells. We have previously reported that suramin blocked the ATPevoked $\left[\mathrm{Ca}^{2+}\right]_{\mathrm{i}}$ responses in cells lacking ATP responses in the virtual absence of extracellular $\mathrm{Ca}^{2+}$; suramin did not affect the UTP responses, suggesting that it behaves as a
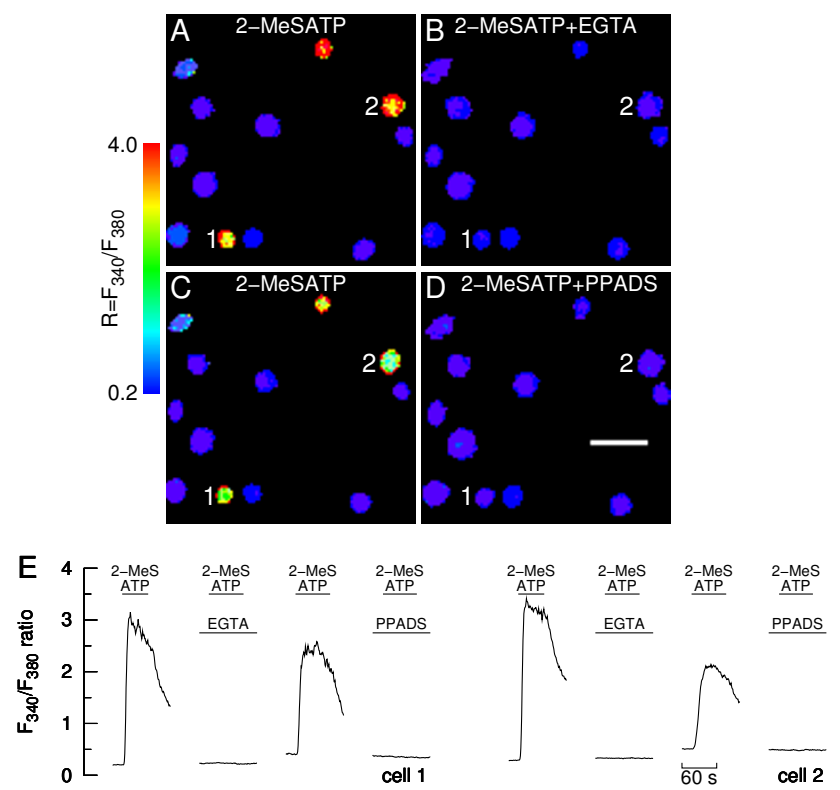

\section{Figure 2}

Effects of PPADS and extracellular $\mathrm{Ca}^{2+}$ removal on calcium responses to 2-MeSATP. A-B. Calcium images showing a group of chromaffin cells during stimulation with $20 \mu \mathrm{M}$ 2-MeSATP in presence of extracellular calcium (A) and during stimulation in the virtual absence of extracellular calcium ("2-MeSATP +EGTA", B); C-D. The cells were subsequently superfused with a $\mathrm{Ca}^{2+}$-containing solution and challenged with 2-MeSATP, in the absence (C) or presence of $50 \mu$ M PPADS ("2-MeSATP +PPADS", D). Calibration bar: $50 \mu \mathrm{m}$. More in the legend to Fig. I(A-D); E. Time courses of changes in $\mathrm{F}_{340} / \mathrm{F}_{380}$ fluorescence ratio for two representative cells (cells $I$ and 2 , also depicted in A-D). The lines denote superfusions with 2-MeSATP, PPADS or EGTA-containing solution. The responses are representative of data from 3 experiments. 
specific P2X receptor antagonist [10]. We have now extended this conclusion to pyridoxalphosphate-6-azophenyl- 2',4'-disulphonic acid (PPADS, $50 \mu \mathrm{M})$. Indeed, the drug blocked the 2-MeSATP $(20 \mu \mathrm{M})$-evoked $\left[\mathrm{Ca}^{2+}\right]_{\mathrm{i}}$ rises in all cells tested ( $\mathrm{n}=9$ cells; Fig. $2 \mathrm{C}, \mathrm{D}, \mathrm{E})$. Moreover, in parallel experiments, PPADS did not affect the UTPevoked $\left[\mathrm{Ca}^{2+}\right]_{\mathrm{i}}$ rises in cells displaying no response to 2$\operatorname{MeSATP}(0.69 \pm 0.33$ vs. $0.73 \pm 0.32$ in absence of PPADS; $\mathrm{n}=11$ cells, $\mathrm{p}=0.1)$.

\section{Effects of purinergic agonists on catecholamine secretion} Both ATP and 2-MeSATP evoked catecholamine secretion in a dose-dependent way, as assessed amperometrically from cell batches (Fig. 3A). In these experiments cells were challenged with brief pulses of either agonist at increasing concentrations, being allowed to rest for $\sim 10$ min between successive applications. The concentration-response curves provided in Fig. 3B suggest that 2-MeSATP might be a more potent agonist for purinergic receptors $\left(\mathrm{EC}_{50}=\right.$ $3.1 \mu \mathrm{M}$ vs. $7.7 \mu \mathrm{M}$ for ATP; but see the Discussion section for a critical assessment of this hypothesis). (Concentrations of test agents are henceforth given as nominal concentrations. Actual concentrations at the cell bed differ from nominal concentrations by a factor of 1.64, see Methods and legend to Fig. 3.) UTP $(100 \mu \mathrm{M})$ did not evoke catecholamine secretion. PPADS $(50 \mu \mathrm{M})$ abolished 2-MeSATP (10 $\mu \mathrm{M})$-evoked secretion (Fig. 3B).

Challenging the cells with $50 \mu \mathrm{M}$ 2-MeSATP in the virtual absence of extracellular calcium failed to elicit secretion (Fig. 3B), indicating that the stimulatory action of the purinoceptor agonist is strictly calcium-dependent. This action may be mediated mostly by activation of voltagesensitive $\mathrm{Ca}^{2+}$ channels, since $0.5 \mathrm{mM} \mathrm{Cd}^{2+}$ (a blocker of these channels) reduced 2-MeSATP-evoked secretion by $73.0 \pm 1.5 \%\left(\mathrm{n}=3\right.$ experiments); $\mathrm{Cd}^{2+}$ inhibited high $\mathrm{K}^{+}$ (50 mM)-evoked catecholamine secretion by $98 \%$ ( $\mathrm{n}=3$ experiments). Replacing extracellular $\mathrm{Na}^{+}$for $\mathrm{N}$-methyl-Dglucamine $\left(\mathrm{NMG}^{+}\right)$abolished 2-MeSATP-evoked secretion (Fig. 3B); tetrodotoxin (TTX, $1 \mu \mathrm{M}$ ) had a modest $(18.5 \pm 3.0 \%, \mathrm{n}=3$ experiments) inhibitory effect on evoked secretion, suggesting that $\mathrm{Na}^{+}$influx through TTXsensitive, voltage-dependent $\mathrm{Na}^{+}$channels played a minimal role.

\section{Discussion}

We found that $\sim 50 \%$ of the cells examined by fluorescence imaging exhibited $\left[\mathrm{Ca}^{2+}\right]_{\mathrm{i}}$ responses to ATP and that, among these, $\sim 40 \%$ yielded positive responses to 2 MeSATP. None of the 2-MeSATP-sensitive cells responded in the virtual absence of extracellular $\mathrm{Ca}^{2+}$. Since cell exposure to EGTA-containing solutions caused minimal depletion of intracellular $\mathrm{Ca}^{2+}$ stores $[1,10]$, this implies that 2MeSATP elicits $\left[\mathrm{Ca}^{2+}\right]_{\mathrm{i}}$ rises by stimulating $\mathrm{Ca}^{2+}$ influx.
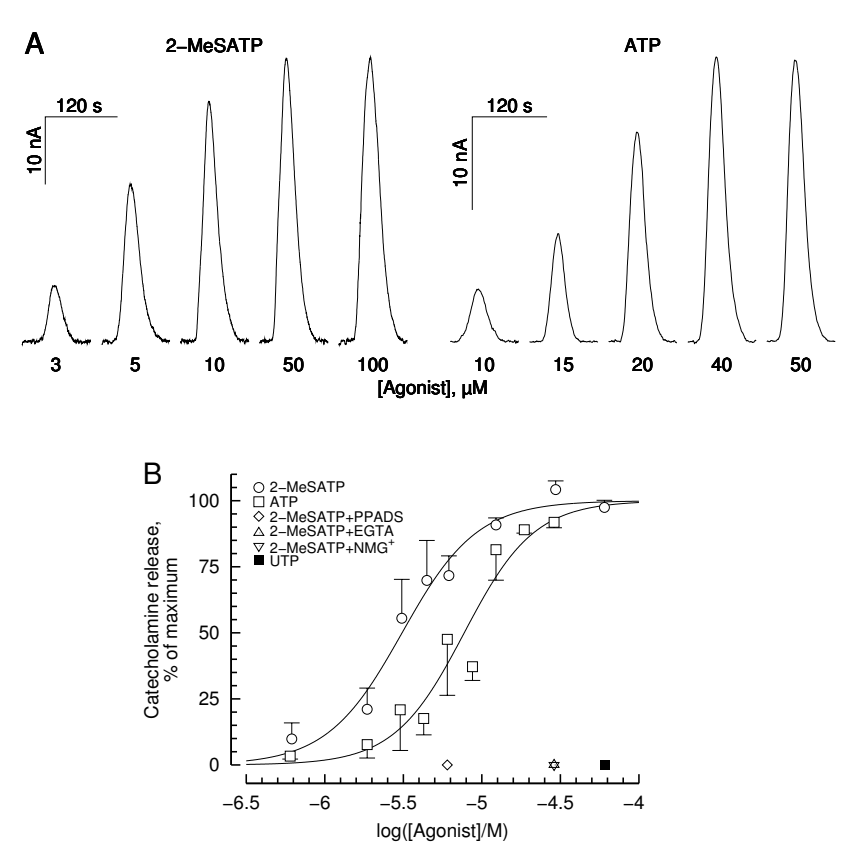

Figure 3

Effects of 2-MeSATP and ATP on catecholamine release. A. Amperometric currents recorded from chromaffin cell batches in response to brief pulses of increasing 2MeSATP and ATP concentrations. Cells were allowed to rest for $\sim 10$ min between successive applications. Nominal agonist concentrations (in $\mu \mathrm{M}$ ) are indicated beneath each trace. Nominal concentrations of test agents are used throughout this legend. Actual concentrations at the cell bed differ from nominal concentrations by a factor of 1.64 (see Methods). Concentrations along the $\mathrm{X}$ axis in Fig. 3B are actual concentrations at the cell bed; $\mathbf{B}$. Dose-response curves of catecholamine release evoked by 2-MeSATP and ATP (circles and squares, respectively). Data from the experiment depicted in $A$ and two similar experiments. Also depicted are data for UTP ( $100 \mu \mathrm{M}$; filled square) as well as for 2-MeSATP stimulations in presence of $50 \mu \mathrm{M}$ PPADS (diamond), in the virtual absence of extracellular $\mathrm{Ca}^{2+}$ (EGTA-containing solution, inverted triangle) and in absence of extracellular $\mathrm{Na}^{+}\left(\mathrm{Na}^{+}\right.$ replacement for $\mathrm{NMG}^{+}$, triangle) $(\mathrm{n}=3$ experiments for each condition).

Hence, 2-MeSATP behaves as a specific P2X receptor agonist in bovine chromaffin cells.

The 2-MeSATP-sensitive P2X receptors in these cells are blocked by low concentrations of suramin [10] and PPADS (this work). In agreement with a previous study [9], we show here that 2-MeSATP is a stronger secretagogue than ATP. This might suggest that ATP is a weaker agonist of the P2X receptor, in apparent disagreement with the information provided by our former $\left[\mathrm{Ca}^{2+}\right]_{i}$ study [11] where the order of potency for purinergic agonists was ATP > 2-MeSATP >> $\alpha \beta$-MeATP, ADP [ $\beta S]$, AMP. We 
note, however, that activation of a P2Y receptor coupled to $G_{i / o}$ inhibits exocytotic release of catecholamines from rat chromaffin cells downstream voltage-sensitive $\mathrm{Ca}^{2+}$ channels and cytosolic $\mathrm{Ca}^{2+}$ elevation [17]. Moreover, activation of $\mathrm{P} 2 \mathrm{Y}$ receptors inhibits voltage-sensitive $\mathrm{Ca}^{2+}$ channels via $G_{i} / G_{0}$ proteins and, thus, depresses $\mathrm{Ca}^{2+}$ dependent exocytosis $[12,13,18-22]$. Subclassification of $\mathrm{P} 2 \mathrm{X}$ receptors in bovine chromaffin cells was clearly outside the objectives of the present functional study. Nonetheless, taking into account the sensitivity to inhibitors, as well as the above order of potency for purinergic agonists, $\mathrm{P} 2 \mathrm{X}$ receptors expressed in bovine chromaffin cells appear to have the pharmacological profile of $\mathrm{P}_{2} \mathrm{X}_{2}$ or $\mathrm{P} 2 \mathrm{X}_{5}$ receptors $[2,4,15]$. As a note of caution we emphasize that P2X receptors in situ most probably are composed of different unit subtypes with a pharmacology distinct from that of the homomeric receptors cloned and transfected to cells, which difficults any attempt at identifying P2X receptor subtypes on the basis of functional studies.

We have also found that $50 \%$ of the ATP-sensitive cells yielded positive responses to UTP. Thus, since UTP is a specific agonist for $\mathrm{P} 2 \mathrm{Y}$ receptors in bovine chromaffin cells [1], approximately half of the ATP-sensitive cell population expressed functional $\mathrm{Ca}^{2+}$-mobilizing P2Y receptors. This agrees with the finding by Ennion et al. that these cells express an as yet unidentified UTP-sensitive, $G_{i}$ / ${ }_{0}$-coupled P2Y receptor [13]. It is noteworthy that the authors also provided evidence for the presence of a $G_{i / o^{-}}$ linked, adenine nucleotide-specific $\mathrm{P} 2 \mathrm{Y}_{12}$ receptor and detected transcripts for $\mathrm{P}_{2} \mathrm{Y}_{1}$ receptors by RT-PCR analysis. Accordingly, our results suggest that bovine chromaffin cells express a $\mathrm{Ca}^{2+}$-mobilizing, UTP-insensitive P2Y receptor. Indeed, $\sim 20 \%$ of the ATP-sensitive pool did not respond to either 2-MeSATP or UTP. Taking into account that P2X receptors are fully sensitive to 2-MeSATP in bovine chromaffin cells, the most likely explanation for this finding is that, indeed, some cells express a $\mathrm{Ca}^{2+}$ mobilizing, UTP-insensitive $\mathrm{P} 2 \mathrm{Y}$ receptor.

Chromaffin cells exist in the form of two major phenotypes, epinephrine-secreting (adrenergic) and norepinephrine-secreting (noradrenergic) cells [23]. Our previous work [1] showed that P2X receptors and UTP-sensitive P2Y receptors are asymmetrically distributed among two distinct cell pools (noradrenergic and adrenergic cells). The present data are fully compatible with this finding. Indeed, approximately $30 \%$ of the ATP-sensitive cells yielded positive responses to 2-MeSATP but not to UTP, suggesting that they express $\mathrm{P} 2 \mathrm{X}$ receptors preferentially. Moreover, approximately $40 \%$ of the ATP-sensitive cells yielded positive responses to UTP but not to 2-MeSATP, suggesting that they express $\mathrm{Ca}^{2+}$-mobilizing P2Y receptors only. A small fraction of the ATP-sensitive cells examined in this study responded both to UTP and 2-MeSATP, suggesting that they co-express $\mathrm{P} 2 \mathrm{X}$ and $\mathrm{P} 2 \mathrm{Y}$ receptors (see also [10]).

There is evidence that stimulated $\mathrm{Ca}^{2+}$ influx is strongly coupled to catecholamine release; in contrast, $\mathrm{Ca}^{2+}$ release from intracellular stores appears to be loosely coupled to secretion $[10,24]$. The present data support this concept, inasmuch as $\mathrm{P} 2 \mathrm{X}$ receptor activation by 2-MeSATP stimulated $\mathrm{Ca}^{2+}$ influx and evoked catecholamine release, whereas activation of $\mathrm{P} 2 \mathrm{Y}$ receptors by UTP elicited $\mathrm{Ca}^{2+}$ release from intracellular stores but did not evoke secretion. We found that, while 2-MeSATP-induced secretion was strictly $\mathrm{Na}^{+}$-dependent, the voltage-sensitive $\mathrm{Na}^{+}$ channel blocker TTX $[25,26]$ inhibited evoked release by a modest $20 \%$. This suggests that voltage-sensitive $\mathrm{Ca}^{2+}$ channels were mostly activated by the depolarization brought about by $\mathrm{Na}^{+}$influx across $\mathrm{P} 2 \mathrm{X}$ receptor pores. That voltage-sensitive $\mathrm{Ca}^{2+}$ channels are involved in 2MeSATP-induced secretion is suggested by the strong inhibitory effect of $\mathrm{Cd}^{2+}$. Indeed, $\mathrm{Cd}^{2+}$ blocks $\mathrm{Ca}^{2+}$ influx across these channels without affecting P2X receptors $[27,28]$.

\section{Conclusion}

2-MeSATP is a specific P2X purinoceptor agonist and a potent secretagogue in bovine chromaffin cells. Activation of $\mathrm{P} 2 \mathrm{X}$ receptors stimulates $\mathrm{Ca}^{2+}$ influx mainly via voltagesensitive $\mathrm{Ca}^{2+}$ channels. For the most part, these are activated by the depolarization brought about by $\mathrm{Na}^{+}$influx across P2X receptor pores.

\section{Methods \\ Cell culture}

Bovine adrenal glands were obtained from the local slaughterhouse and kept on ice during transportation. Adrenal medulla cells were isolated by collagenase digestion of the glands and purified on a Percoll density gradient essentially as described previously [29,30]. The purified cell fraction thus obtained is enriched in chromaffin cells. Cells were cultured according to established procedures [1]. For the fluorescence imaging experiments, the cells were plated on round (16 mm diameter) glass coverslips coated with poly-L-lysine. For the secretion experiments, the cells were cultured in $60 \mathrm{~mm}$ diameter plastic Petri-dishes. Cells were typically used between days 2 and 5 after plating.

\section{Solutions}

The $\mathrm{Ca}^{2+}$-containing salt solution used in the imaging and secretion experiments had the following composition (mM): $140 \mathrm{NaCl}, 5 \mathrm{KCl}, 2 \mathrm{CaCl}_{2}, 1 \mathrm{MgCl}_{2}, 10 \mathrm{mM}$ HEPES and 10 glucose ( $\mathrm{pH} 7.4)$. In some experiments extracellular free $\left[\mathrm{Ca}^{2+}\right]$ was buffered at $100 \mathrm{nM}$ by mixing appropriate amounts of $\mathrm{Ca}^{2+}$ and EGTA, as described elsewhere [31]. 


\section{$\left[\mathrm{Ca}^{2+}\right]_{i}$ imaging}

The coverslips containing the cells were washed in physiological saline supplemented with $1 \%$ bovine serum albumin (BSA). The cells were then loaded with $2.5 \mu \mathrm{M}$ fura2/AM (the acetoxymethyl ester of fura-2 [32]) for $45 \mathrm{~min}$ at $37^{\circ} \mathrm{C}$ in this medium, under a $95 \% \mathrm{O}_{2} / 5 \% \mathrm{CO}_{2}$ atmosphere. Cell handling after loading was carried out following established procedures. Specifically, cells were continuously perifused (approximately $1.5 \mathrm{ml} / \mathrm{min}$ ) with physiological saline at room temperature. Solution exchange was provided by a four-way stopcock valve located near the recording chamber $[1,10,11]$. Fluorescence changes were recorded using a multiple excitation MagiCal imaging system (Applied Imaging, U.K.), essentially as described $[1,33]$.

\section{Catecholamine secretion}

Catecholamine secretion from chromaffin cells was measured on-line using a perifusion system similar to that described previously [34]. Approximately $10^{6}$ cells were placed in a $0.45 \mu \mathrm{m}$ flow filter and perifused with the HEPES-containing solution with the aid of a peristaltic pump (Gilson Miniplus 3) at a rate of $1 \mathrm{ml} / \mathrm{min}$. Test drugs were added as brief pulses through a $500-\mu$ l loop injector. Taking into account the dead volume of the filter chamber and the flow rate, the actual concentration of a given drug inside the chamber (cell bed) was reduced by a factor of 1.64. Thus, while drug concentrations are given as nominal concentrations throughout the main text and legend to Fig. 3, the concentrations along the $\mathrm{X}$ axis in Fig. $3 \mathrm{~B}$ are corrected for the dilution factor (i.e. they refer to the actual concentrations acting on cells). The effluent solution exiting the filter was driven into an electrochemical detector (set at $+500 \mathrm{mV}$, Omni 90 Potentiostat, Cypress Systems, Lawrence, KS) for direct measurement of catecholamine oxidation current, which was monitored on a chart recorder.

\section{Data analysis}

Data are presented as mean \pm S.D. Statistical significance of differences was assessed by paired (within the same experiment) or unpaired (between experiments) Student's t-test; differences were considered significant at the 95\% confidence level $(\mathrm{P}<0.05)$.

\section{Other materials}

Fura-2/AM was from Molecular Probes (Eugene, Ore., USA). ATP was from Boehringer (Mannheim, Germany). Unless otherwise specified, all other chemicals were from Sigma Chemical Co. (St. Louis, Mo., USA).

\section{Authors' contributions}

ART carried out the experiments, performed the statistical analysis, prepared the figures, participated in conceiving and designing the study, and helped to draft the manu- script; EC helped in carrying out the experiments and participated in conceiving and designing the study; RMS helped to draft the manuscript; LMR participated in conceiving and coordinating the study and drafted the manuscript. All authors read and approved the final manuscript.

\section{Acknowledgements}

This work was partially financed by a grant from FCT (Fundação para a Ciência e a Tecnologia, Portugal). Dr. E. Castro was supported by a FEBS fellowship. The facilities provided by the Faculty of Medicine (University of Coimbra) are gratefully acknowledged.

\section{References}

I. Tomé AR, Castro E, Santos RM, Rosário LM: Functional distribution of $\mathrm{Ca2}+$-coupled $\mathrm{P} 2$ purinergic receptors among adrenergic and noradrenergic bovine adrenal chromaffin cells. BMC Neurosci 2007, 8(I):39.

2. Ralevic $V$, Burnstock G: Receptors for purines and pyrimidines. Pharmacol Rev 1998, 50:413-492.

3. Dunn PM, Zhong Y, Burnstock G: $\mathbf{P 2 X}$ receptors in peripheral neurons. Prog Neurobiol 200I, 65:107-I34.

4. Liu M, Dunn PM, King BF, Burnstock G: Rat chromaffin cells lack $\mathrm{P} 2 \mathrm{X}$ receptors while those of the guinea-pig express a $\mathrm{P} 2 \mathrm{X}$ receptor with novel pharmacology. $B r$ J Pharmacol 1999, I 28:6I-68.

5. Afework $M$, Burnstock $G$ : Distribution of $\mathbf{P} \mathbf{2 X}$ receptors in the rat adrenal gland. Cell Tissue Res 1999, 298:449-456.

6. Vulchanova L, Arvidsson U, Riedl M, Wang J, Buell G, Surprenant A, North RA, Elde R: Differential distribution of two ATP-gated channels (P2X receptors) determined by immunocytochemistry. Proc Natl Acad Sci USA 1996, 93:8063-8067.

7. Afework M, Burnstock G: Age-related changes in the localization of $\mathbf{P} 2 X$ (nucleotide) receptors in the rat adrenal gland. Int J Dev Neurosci 2000, 1 8:5 I5-520.

8. Afework M, Burnstock G: Localization of $\mathbf{P} 2 \mathbf{X}$ receptors in the guinea pig adrenal gland. Cells Tissues Organs 2000, 167:297-302.

9. Reichsman F, Santos S, Westhead EW: Two distinct ATP receptors activate calcium entry and internal calcium release in bovine chromaffin cells. J Neurochem 1995, 65:2080-2086.

10. Castro E, Mateo J, Tome AR, Barbosa RM, Miras-Portugal MT, Rosario LM: Cell-specific purinergic receptors coupled to $\mathrm{Ca2+}$ entry and $\mathrm{Ca} 2+$ release from internal stores in adrenal chromaffin cells. Differential sensitivity to UTP and suramin. J Biol Chem 1995, 270:5098-5I06.

II. Castro E, Tome AR, Miras-Portugal MT, Rosario LM: Single-cell fura-2 microfluorometry reveals different purinoceptor subtypes coupled to $\mathrm{Ca2}+$ influx and intracellular $\mathrm{Ca} 2+$ release in bovine adrenal chromaffin and endothelial cells. Pflugers Arch 1994, 426:524-533.

12. Diverse-Pierluissi M, Dunlap K, Westhead EW: Multiple actions of extracellular ATP on calcium currents in cultured bovine chromaffin cells. Proc Natl Acad Sci USA 199|, 88: | 26I-I 265.

13. Ennion SJ, Powell AD, Seward EP: Identification of the P2Y(I2) receptor in nucleotide inhibition of exocytosis from bovine chromaffin cells. Mol Pharmacol 2004, 66:60 I-6II.

14. Lin LF, Bott MC, Kao LS, Westhead EW: ATP stimulated catecholamine secretion: response in perfused adrenal glands and a subpopulation of cultured chromaffin cells. Neurosci Lett 1995, 183:147-I50.

15. Burnstock G: Historical review: ATP as a neurotransmitter. Trends Pharmacol Sci 2006, 27:166-I76.

16. Otsuguro K, Asano T, Ohta T, Ito S, Nakazato Y: ATP-evoked membrane current in guinea pig adrenal chromaffin cells. Neurosci Lett 1995, I 87:|45-|48.

17. Chen XK, Wang LC, Zhou Y, Cai Q, Prakriya M, Duan KL, Sheng ZH, Lingle C, Zhou Z: Activation of GPCRs modulates quantal size in chromaffin cells through G(betagamma) and PKC. Nat Neurosci 2005, 8: I160-1 I68.

18. Lim W, Kim SJ, Yan HD, Kim J: Ca2+-channel-dependent and independent inhibition of exocytosis by extracellular ATP in 
voltage-clamped rat adrenal chromaffin cells. Pflugers Arch 1997, 435:34-42.

19. Powell AD, Teschemacher AG, Seward EP: P2Y purinoceptors inhibit exocytosis in adrenal chromaffin cells via modulation of voltage-operated calcium channels. J Neurosci 2000, 20:606-616.

20. Hernandez-Guijo JM, Gandia L, Cuchillo-lbanez I, Albillos A, Novalbos J, Gilsanz F, Larranaga E, de PR, Abad F, Garcia AG: Altered regulation of calcium channels and exocytosis in single human pheochromocytoma cells. Pflugers Arch 2000, 440:253-263.

21. Harkins AB, Fox AP: Activation of purinergic receptors by ATP inhibits secretion in bovine adrenal chromaffin cells. Brain Res 2000, 885:23I-239.

22. Ulate G, Scott SR, Gonzalez J, Gilabert JA, Artalejo AR: Extracellular ATP regulates exocytosis in inhibiting multiple $\mathbf{C a}(2+)$ channel types in bovine chromaffin cells. Pflugers Arch 2000, 439:304-3I4.

23. Moro MA, Lopez MG, Gandia L, Michelena P, Garcia AG: Separation and culture of living adrenaline- and noradrenaline-containing cells from bovine adrenal medullae. Anal Biochem 1990 I 85:243-248.

24. Burgoyne RD: Control of exocytosis in adrenal chromaffin cells. Biochim Biophys Acta 1991, I 07 I:174-202.

25. Brandt BL, Hagiwara S, Kidokoro Y, Miyazaki S: Action potentials in the rat chromaffin cell and effects of acetylcholine. J Physiol 1976, 263:417-439.

26. Fenwick EM, Marty A, Neher E: Sodium and calcium channels in bovine chromaffin cells. J Physiol 1982, 331:599-635.

27. Nakazawa K, Inoue K: Roles of $\mathbf{C a 2}+$ influx through ATP-activated channels in catecholamine release from pheochromocytoma PCI 2 cells. J Neurophysiol 1992, 68:2026-2032.

28. Boehm S: ATP stimulates sympathetic transmitter release via presynaptic P2X purinoceptors. J Neurosci 1999, 19:737-746.

29. Rosario LM, Soria B, Feuerstein G, Pollard HB: Voltage-sensitive calcium flux into bovine chromaffin cells occurs through dihydropyridine-sensitive and dihydropyridine- and omegaconotoxin-insensitive pathways. Neuroscience 1989, 29:735-747.

30. Rosario LM, Stutzin A, Cragoe EJ Jr, Pollard HB: Modulation of intracellular $\mathrm{pH}$ by secretagogues and the $\mathrm{Na}+\mathrm{H}+$ antiporter in cultured bovine chromaffin cells. Neuroscience 1991, 41:269-276.

31. Marks PW, Maxfield FR: Preparation of solutions with free calcium concentration in the nanomolar range using I,2-bis(oaminophenoxy)ethane-N,N,N',N'-tetraacetic acid. Anal Biochem |99|, | 93:6I-7I.

32. Grynkiewicz G, Poenie M, Tsien RY: A new generation of Ca2+ indicators with greatly improved fluorescence properties. J Biol Chem 1985, 260:3440-3450.

33. Oset-Gasque MJ, Vicente S, Gonzalez MP, Rosario LM, Castro E: Segregation of nitric oxide synthase expression and calcium response to nitric oxide in adrenergic and noradrenergic bovine chromaffin cells. Neuroscience 1998, 83:27I-280.

34. Castro E, Torres M, Miras-Portugal MT, Gonzalez MP: Effect of diadenosine polyphosphates on catecholamine secretion from isolated chromaffin cells. Br J Pharmacol 1990, 100:360-364.
Publish with Biomed Central and every scientist can read your work free of charge

"BioMed Central will be the most significant development for disseminating the results of biomedical research in our lifetime. "

Sir Paul Nurse, Cancer Research UK

Your research papers will be:

- available free of charge to the entire biomedical community

- peer reviewed and published immediately upon acceptance

- cited in PubMed and archived on PubMed Central

- yours - you keep the copyright
BioMedcentral 